\title{
Flowering catch crops used as forage plants for dairy cows: Influence on fatty acids and tocopherols in milk
}

\author{
T. Kälber, J. S. Meier, M. Kreuzer, and F. Leiber ${ }^{1}$ \\ ETH Zurich, Institute of Agricultural Sciences, Universitaetsstrasse 2, CH-8092 Zurich, Switzerland
}

\begin{abstract}
The effect of several flowering dicotyledonous catch crop plants (dicots) on milk fat quality in cows was investigated to test the hypothesis that their phenolic compounds may inhibit ruminal biohydrogenation and thus enhance the transfer to milk of intact, plantderived polyunsaturated fatty acids. Berseem clover (Trifolium alexandrinum), buckwheat (Fagopyrum esculentum), and phacelia (Phacelia tanacetifolia) were sown in mixture with ryegrass (Lolium multiflorum; intended biomass proportion of 0.2 ) on 1 ha. For comparison, nonflowering chicory (Cichorium intybus, also sown in mixture with ryegrass) and pure ryegrass were cultivated. Realized biomass proportions (wet weight) were $91 \%$ for berseem clover, $69 \%$ for buckwheat, $54 \%$ for phacelia, and $51 \%$ for chicory. At the start of flowering (or from d 47 after sowing onward), cultures were harvested daily and fed for $20 \mathrm{~d}$ ad libitum to groups of 6 midlactation cows each. Additionally, $1 \mathrm{~kg}$ each of energy and protein concentrate and pure ryegrass hay were fed. Individual intake and milk yield of the cows were measured daily. Milk samples were obtained twice daily $5 \mathrm{~d}$ before and from 11 to $20 \mathrm{~d}$ after the start of treatment feeding. Feed samples were drawn twice a week from the fresh feeds. Apart from standard traits, feeds and milk were analyzed for fatty acids, tocopherols, and phenolic fractions. Only a few substantial treatment effects on intake and performance were observed. All diets based on dicots increased $\alpha$-linolenic acid (ALA) concentrations in milk fat compared with the ryegrass diet even though the corresponding swards were not generally richer in ALA. The highest ALA concentration in milk fat $(1.3 \mathrm{~g} / 100 \mathrm{~g}$ of fatty acids) occurred with the berseem clover diet. Transfer rate of ALA from feed to milk was highest with the buckwheat diet (0.09) and lowest with ryegrass (0.05). This was congruent with the differences in total extractable phenols, being high in the buckwheat sward $(2.6 \%$ of
\end{abstract}

Received August 18, 2010.

Accepted November 7, 2010.

${ }^{1}$ Corresponding author: fleiber@ethz.ch dry matter) and low in the ryegrass sward (1.2\% of dry matter). Intermediates of ALA biohydrogenation were lowest in the milk fat of the buckwheat group, indicating an inhibitory effect of this treatment, which provided the highest dietary levels of phenols. The $\alpha$-tocopherol concentration in milk was higher with the buckwheat diet than with berseem clover and phacelia diets. The study provides evidence that the ALA concentration in milk fat could be enhanced by feeding flowering dicots; however, this was due to different modes of action.

Key words: biohydrogenation, flowering herb, linolenic acid, phenol

\section{INTRODUCTION}

Repeatedly, research has shown that concentrations of the cis- $(\boldsymbol{c}) 9$, trans- $(\boldsymbol{t}) 11$ isomer of conjugated linolenic acid (18:2 $c 9, t 11$; rumenic acid; RA) and $\alpha$-linolenic acid (18:3 n-3; ALA) in milk fat can be enhanced by high-forage diets and particularly by grazing of lactating cows (Dewhurst et al., 2006) and small ruminants (Sanz Sampelayo et al., 2007). The RA is a direct and indirect product of ruminal biohydrogenation of dietary linoleic acid (18:2 n-6; LA) and ALA (Jenkins et al., 2008). By contrast, ALA in the endogenous metabolism and milk originates directly from the diet. Therefore, a high level depends not only on dietary intake but also on an elevated ruminal bypass of this fatty acid (FA) in an intact form. It has been hypothesized that the markedly increased transfer rate for ALA from forage to milk found in cows grazing alpine compared with lowland pastures is a result of reduced biohydrogenation. This inhibition could be caused by plant secondary compounds coming along with the high proportion of flowering dicotyledonous plants in these swards (Leiber et al., 2005). This hypothesis is supported by a study of Cabiddu et al. (2005), which showed an increase of ALA in milk fat when replacing ryegrass by sulla, and by replacing sulla in its vegetative stage with sulla in its reproductive stage. Recently, the same research group (Cabiddu et al., 2010) demonstrated in vitro a negative relationship between ALA biohydrogenation rate and relative concentrations of tannic phenols in forage plants. 
In the lowlands of regions with a temperate climate, flowering catch crops, which may form an element of crop rotations practiced in arable regions, might provide a similar opportunity to enrich the diet of cows with plants being bioactive in this respect. Some of these plants are not only underutilized as forages, but also are rarely investigated. Berseem clover is a common forage legume that is well cultivable as a catch crop. It is reported to contain a large amount of different phenols, such as clovamides, phenolic acids, flavonoids, and isoflavones (Oleszek et al., 2007; Prati et al., 2007). Unlike other clover species, berseem clover does not cause bloat in ruminants and therefore can be fed alone (Sims et al., 1991). Buckwheat as a whole plant is not commonly used in ruminant feeding, but its suitability as a diet component has recently been demonstrated in dairy cows (Amelchanka et al., 2010). Its concentration of phenolic compounds is comparably high for plants in temperate climatic regions (Wijngaard and Arendt, 2006), which may prevent ALA from peroxidation in organisms of the next trophic level (Hinneburg et al., 2006). This makes the plant one of interest in the current context of ALA metabolism in cows. Further, flowering buckwheat has a high ecological value, providing feed for honey bees and wild insects in late summer (Wijngaard and Arendt, 2006). The same is true for the intensively flowering phacelia, which is commonly used for soil melioration in Europe, but has scarcely been evaluated as a forage plant for cows (Rubach, 1957; Daniel and Zobelt, 1986).

The present experiment was designed to test the following hypotheses: (1) the effect of flowering dicots on ALA transfer from feed to milk is reproducible among plant species, (2) a clear species effect exists when comparing flowering and nonflowering dicots, and (3) the favorable "alpine pasture effect" on milk fat composition also can be reproduced in more intensive lowland land use systems by feeding catch crop dicots. The 3 aforementioned catch crop species were chosen with the aim to have plants that could be interesting as ruminant feed, which intensively flower and which are of different botanical families. The use of these plants as fresh forage components in high proportions in comparison with a nonflowering dicot forage (chicory) and ryegrass, in conjunction with a detailed analysis of phenolic fractions and tocopherols in forages and milk, was expected to give useful insight to answer the aforementioned questions.

\section{MATERIALS AND METHODS}

\section{Experimental Plants}

Three flowering catch crop species, berseem clover (Trifolium alexandrinum var. Sacromonte), buckwheat
(Fagopyrum esculentum var. Lileija), and phacelia (Phacelia tanacetifolia var. Facita); 1 biennial herb species, chicory (Cichorium intybus var. Puna); and 1 grass species, ryegrass (Lolium multiflorum ssp. westerwoldicum var. Saproso) were used as test forages in the study. All forages were sown at the ETH Research Station Chamau (Zug, Switzerland; $400 \mathrm{~m}$ above sea level) in June 2008. Seeds were obtained from UFA Samen (Fenaco Sämereienzentrum Niderfeld, Winterthur, Switzerland). The dicots were sown in mixture with ryegrass in seed proportions of 0.80:0.20 calculated from the 1,000-seed weight of the plants. From wk 4 after sowing onward, yields as well as test plant, ryegrass, and weed proportions were assessed weekly by sample cuts on five $20 \mathrm{~cm} \times 50 \mathrm{~cm}$ plots per sward, followed by sorting and weighing. After the dicots reached their flowering state, the swards were cut daily in the morning to be fed in fresh form. Buckwheat started flowering $35 \mathrm{~d}$ after sowing; feeding started from 47 $\mathrm{d}$ after sowing onward. The corresponding dates were $49 \mathrm{~d}$ and $54 \mathrm{~d}$ for phacelia and berseem clover. Like the buckwheat, the 2 nonflowering species, chicory and ryegrass, were fed from $47 \mathrm{~d}$ after sowing onward. At that time, ryegrass had been in the state of ear emergence. Feeding of the test plants lasted for $20 \mathrm{~d}$.

\section{Animals and Experimental Design}

Thirty lactating dairy cows (25 Holstein and 5 Brown Swiss) were included in the experiment. On average, the cows weighed $662 \pm 68 \mathrm{~kg}$ (mean $\pm \mathrm{SD}$ ), were $162 \pm 83$ DIM, and yielded $28.4 \pm 8.7 \mathrm{~kg}$ of ECM, as measured 1 wk before the start of the experiment. The cows were allocated to 5 treatments corresponding to the 5 different swards $(n=6)$ in a completely randomized design. Groups were balanced for breed, ECM, DIM, and milk fat and protein content. The animals were housed in a free-ranging barn in groups of 6 per capita. During the experiment, data sets of 2 Holstein cows had to be excluded, 1 due to mastitis (ryegrass group) and the other because of a foreign body in the rumen (buckwheat group). The experimental design was approved by the cantonal veterinary office of Zug, Switzerland (approval No. ZG 48/07).

\section{Experimental Schedule}

The experiment lasted for $25 \mathrm{~d}$ and was subdivided into 3 periods: a baseline period (lasting for $5 \mathrm{~d}$ ), an adaptation period $(10 \mathrm{~d})$, and a main data and sample collection period (10 d). During the baseline period, cows were fed a mixed forage ration ad libitum consisting of $560 \mathrm{~g}$ of grass silage $/ \mathrm{kg}$ of DM; maize 260 $\mathrm{g}$ of silage $/ \mathrm{kg}$ of $\mathrm{DM}$; and $180 \mathrm{~g}$ of hay $/ \mathrm{kg}$ of $\mathrm{DM}$. 
This forage ration was supplemented with $120 \mathrm{~g} / \mathrm{d}$ of a commercial mineral-vitamin premix (KM $2417 \mathrm{P} /$ TMR, Kroni Locher \& Co. AG, Altstaetten, Switzerland) and dairy concentrates (UFA 245 PRIMA and UFA 248 PRIMA, UFA AG, Herzogenbuchsee, Switzerland) offered in amounts covering the remaining requirements for milk yield. This resulted in an average forage:concentrate ratio of 2.7:1. The adaptation period served for the gradual adaptation to the new forages and lower concentrate allocations. Replacement of baseline diets by experimental diets was $0.33,0.5$, 0.67 , and 0.83 on experimental d 6/7, 8, 9/10, and 11 . From d 6 to 10, concentrate levels were reduced by 0.5 $\mathrm{kg} / \mathrm{d}$ to a final level of $2 \mathrm{~kg} / \mathrm{d}$ (as fed). From d 12 to 25 , only the experimental diets were fed, as described below.

The experimental forage swards, which had been cut in the morning, were offered at 0630, 1030, 1300, 1430, 1645, and $1930 \mathrm{~h}$ in amounts that allowed for unrestricted intake but that were still consumed almost completely. The resulting small amounts of refusals were considered for DMI, but were not further analyzed. Cows were additionally supplemented with 1.1 $\mathrm{kg}$ of DM of pure ryegrass (Lolium perenne) hay (first cut, state of ear emergence) after each milking at 0545 and $1600 \mathrm{~h}$ to guarantee diets with sufficient property of fibrousness. These amounts were always consumed completely. Two concentrates were used to complement the diets with energy (899 g of DM/kg; consisting 348 $\mathrm{g}$ of corn $/ \mathrm{kg}$ of DM, $312 \mathrm{~g}$ of wheat bran $/ \mathrm{kg}$ of DM, $250 \mathrm{~g}$ of wheat $/ \mathrm{kg}$ of DM, $50 \mathrm{~g}$ of sugar beet molasses/ $\mathrm{kg}$ of DM, $25 \mathrm{~g}$ of straw meal $/ \mathrm{kg}$ of DM, and $15 \mathrm{~g}$ of soybean oil/kg of DM) and with protein (912 $\mathrm{g}$ of DM/ $\mathrm{kg} ; 788 \mathrm{~g}$ of soybean meal $/ \mathrm{kg}$ of DM, $114 \mathrm{~g}$ of corn gluten $/ \mathrm{kg}$ of DM, $50 \mathrm{~g}$ of sugar beet molasses $/ \mathrm{kg}$ of $\mathrm{DM}$, and $38 \mathrm{~g}$ of potato protein $/ \mathrm{kg}$ of DM; concentrates from UFA AG). These concentrates were allocated in amounts of $1 \mathrm{~kg} / \mathrm{d}$ (as fed) each to all cows to avoid serious imbalances. Together with the concentrate, cows were supplemented with $150 \mathrm{~g} / \mathrm{d}$ of a mineral-vitamin premix (KM1379 W/R, Kroni Locher \& Co. AG). This premix contained (per kg): Ca, $170 \mathrm{~g} ; \mathrm{P}, 50 \mathrm{~g} ; \mathrm{Mg}, 80$ g; Na, 40 g; Zn, 4 g; Mn, 2 g; Cu, 0.5 g; Se, 30 mg; I, 20 mg; Co, $15 \mathrm{mg}$; vitamin A, 800,000 IU; vitamin $\mathrm{D}_{3}, 120,000 \mathrm{IU}$; $\alpha$-tocopherol, $1.65 \mathrm{~g}$. Half of the daily amounts of concentrates and premix always were put into the forage troughs after the hay portion had been consumed by the cows.

The collection period was divided into 3 subperiods $(\mathbf{S P} ; \mathrm{SP} 1=\mathrm{d} 16$ to $18, \mathrm{SP} 2=\mathrm{d} 20$ to $22, \mathrm{SP} 3=\mathrm{d}$ 23 to 25$)$ to be able to follow adaptation processes to the experimental forages and to the progressing phenological state of the forages. Forage intake from the 6 troughs per pen was continuously and individually re- corded by a computerized feeding system equipped with Calan doors (Westfalia Landtechnik, Oelde, Germany). In the collection period, forage samples were taken at experimental d 15, 18, 22, and $25(\mathrm{n}=4)$; hay and concentrate were sampled once. An aliquot of each feed sample was dried at $60^{\circ} \mathrm{C}$ for $48 \mathrm{~h}$ and milled afterward through a 1-mm sieve. Throughout the entire experimental period, the cows were milked daily at 0500 and $1540 \mathrm{~h}$, and milk yields were recorded automatically at each milking (Metatron, Westfalia Landtechnik, Oelde, Germany). In the baseline, during the last $3 \mathrm{~d}$ of the adaptation and collection periods, milk samples were taken at each milking. One aliquot was preserved with 2-bromo-2-nitropropane-1,3-diol (Bronopol, D\&F Inc., Dublin, CA) and stored at $4^{\circ} \mathrm{C}$ until analysis of gross nutrients. Another aliquot was stored at $-20^{\circ} \mathrm{C}$ without any additive. These samples were later pooled accordingly to individual milk amount for the 5-d baseline period and the three 3-d subperiods for later laboratory analysis. The BW of the cows was measured daily after the morning milking and animals were scored by 1 trained person on d 4 (baseline period), 17, and 24 (collection period) using the BCS grading scheme by Ferguson et al. (1994).

\section{Feed Analysis}

Feeds were analyzed for proximate contents using standard procedures (Van Soest et al., 1991; AOAC, 1997). For determination of DM and total ash, an automatic thermogravimetric determinator was used (TGA-500, Leco, St. Joseph, MI; AOAC, 1997; method no. 942.05). Nitrogen was quantified with a $\mathrm{C} / \mathrm{N}$ analyzer (Analysator CN-2000, Leco; AOAC, 1997; method no. 977.02) and $\mathrm{CP}$ was calculated as $\mathrm{N} \times 6.25$. The detergent fiber fractions (NDF, ADF, and acid detergent lignin) were analyzed following Van Soest et al. (1991). a-Amylase was used for NDF determination and detergent fiber data was corrected for ash content. Petroleum ether extract was measured with a Soxhlet extractor (Extraktionssystem B-811, Büchi, Flawil, Switzerland; AOAC index No. 963.15).

Lipids in the feed were extracted by accelerated solvent extraction (ASE 200, Dionex Corp., Sunnyvale, CA) with hexane:propan-2-ol (3:2 vol/vol) and transformed into FA methyl esters (FAME) and cleaned following the procedure described by Wettstein et al. (2001). Internal standards C11:0 and C21:0 (Fluka, Steinheim, Germany) were added. The FAME were analyzed with a gas chromatograph (model HP 6890, equipped with a flame ionization detector, Hewlett-Packard, Palo Alto, CA $)$ on a Supelcowax-10 column $(30 \mathrm{~m} \times 0.32$ mm, $0.25 \mu \mathrm{m}$; Supelco Inc., Bellefonte, PA) after split injection $(1: 30)$ at $270^{\circ} \mathrm{C}$. The injection volume was 2 
$\mu \mathrm{L}$; hydrogen flow was $2.2 \mathrm{~mL} / \mathrm{min}$. The temperature program was the same as that described in Leiber et al. (2005). Sunflower oil was used as an external standard for calculation of the response factor.

Feed samples were analyzed for $\alpha_{-}, \beta-, \gamma-$, and $\delta$-tocopherols after saponification with $\mathrm{KOH}\left(\right.$ at $95^{\circ} \mathrm{C}$ for 30 min under permanent gentle shaking conditions) with a normal-phase HPLC (La Chrom equipped with UV/VIS detection, Merck-Hitachi; Darmstadt, Germany) following Rettenmaier and Schüep (1992).

Total extractable phenols (TEP), total tannins (TT), and condensed tannins (CT) in feeds were quantified following the procedure of Makkar (2003) with slight modifications: gallic acid and polyvinyl-polypyrrolidone were used to separate nontannin phenols from TT. The CT were analyzed using the butanol-HCl-iron method. Both TEP and TT were expressed as gallic acid equivalent, whereas CT were expressed as leucocyanidin equivalents.

Non-NDF carbohydrates were calculated as follows (where EE is ether extract):

$$
\begin{gathered}
\text { Non-NDF carbohydrates }= \\
\mathrm{OM}-\mathrm{NDF}-\mathrm{CP}-\mathrm{EE}-\mathrm{TEP} .
\end{gathered}
$$

\section{Milk Analysis}

Fat, protein, and lactose were analyzed in the Bronopol-conserved samples by near-infrared technique (MilkoScan 4000, Foss Electric, Hillerød, Denmark).

For FA analysis, milk samples were defrosted and gently mixed. Subsequently, $0.5 \mathrm{~mL}$ was diluted in $\mathrm{n}-$ heptane $(5 \mathrm{~mL})$, containing triundecanin, tetradecen, pelargonic acid methyl esters, and trivalerin as internal standards. These solutions were treated with Na-methylate for cold transesterification as described by Suter et al. (1997). The FAME obtained were analyzed with the same gas chromatograph used for feed, but with a SIL88 column $(100 \mathrm{~m} \times 0.25 \mathrm{~mm}, 0.2 \mu \mathrm{m}$; Varian Inc., Darmstadt, Germany). The FAME were injected with a split of 1:30 and an injection volume of $1 \mu \mathrm{L}$. Hydrogen was used as carrier gas with a flow of $1.5 \mathrm{~mL} / \mathrm{min}$, which was kept until the end of the analysis. The temperature program had been adapted with slight modifications from Collomb and Bühler (2000) and is described in Leiber et al. (2005). The FA were identified based on a FAME standard (Supelco 37 component, Supelco Inc.) and by comparison with chromatograms for milk lipids obtained by similar approaches (Collomb and Bühler, 2000; Kramer et al., 2002; Leiber et al., 2005). Individual FA content data were adjusted by using external response factors to correct for the lower response of short-chain FA compared with medium- and long-chain FA.

In similarly defrosted milk samples, tocopherols in milk were analyzed by the same method applied to the feeds. Contents of TEP were determined in $2 \mathrm{~mL}$ of the defrosted milk. At first, $6 \mathrm{~mL}$ of methanol was added, mixed carefully, and centrifuged at $12,000 \times \mathrm{g}$ at $4^{\circ} \mathrm{C}$ for 10 min (Avanti J20XPI, Beckman Coulter, Brea, CA) to precipitate proteins following the method of Ferruzzi and Green (2006). Immediately afterward, 100 $\mu \mathrm{L}$ of the supernatant was transferred into a $3.5-\mathrm{mL}$ tube (Sarstedt, Nümbrecht, Germany), filled up to 500 $\mu \mathrm{L}$ with $\mathrm{H}_{2} \mathrm{O}$ before $250 \mu \mathrm{L}$ of Folin reagent was added and then mixed. Finally, $1.25 \mathrm{~mL}$ of sodium carbonate solution was added and samples were incubated in the dark for at least $40 \mathrm{~min}$. The absorbance was measured at $725 \mathrm{~nm}$ (UV-160 A, Shimadzu Corp., Kyoto, Japan). Calculation of TEP was done as described by Makkar (2003) and expressed as gallic acid equivalents.

\section{Calculations and Statistical Evaluation}

The ECM $(\mathrm{kg} / \mathrm{d})$ was calculated as milk $(\mathrm{kg} / \mathrm{d}) \times$ $(0.38 \times$ fat $\%+0.24 \times$ protein $\%+0.17 \times$ lactose $\%) / 3.14$ (ALP, 2008). Data were subjected to ANOVA using the MIXED procedure of SAS (version 9.2, SAS Institute Inc., Cary, NC). Three different models were applied. In model [1], where $\mathrm{Y}$ is the variable, the baseline period $(\mathrm{Z})$ served as the covariate for all milkrelated traits and each subperiod was tested separately using a model for repeated measurements with treatment $(\mathrm{T})$, subperiod $(\mathrm{S})$, and the interaction $\mathrm{T} \times \mathrm{S}$ as fixed effects and $\varepsilon$ as the residual error term:

$$
\mathrm{Y}_{\mathrm{ij}}=\mathrm{T}_{\mathrm{i}}+\mathrm{S}_{\mathrm{j}}+(\mathrm{T} \times \mathrm{S})_{\mathrm{ij}}+\operatorname{cov}(\mathrm{Z})+\varepsilon_{\mathrm{ijk}} .
$$

All other variables were analyzed with model [2], also considering repeated measurements and testing each subperiod separately as described for model [1] but without including covariates:

$$
\mathrm{Y}_{\mathrm{ij}}=\mathrm{T}_{\mathrm{i}}+\mathrm{S}_{\mathrm{j}}+(\mathrm{T} \times \mathrm{S})_{\mathrm{ij}}+\varepsilon_{\mathrm{ijk}} .
$$

Model [3] was used for testing BW change and BCS change. Both parameters were calculated by subtracting the according baseline value from the value in subperiod 3 and analyzed by ANOVA with the treatment as a fixed factor. Multiple comparisons among the treatment means were determined by Tukey's method, and differences were considered significant at $P<0.05$. The tables and the figure display least squares means and standard error of the mean. 


\section{RESULTS}

\section{Experimental Plants}

The cultures grew well, but developed somewhat differently. The realized wet weight proportions of berseem clover, buckwheat, phacelia, and chicory within the respective cultivations were $91.1,68.8,54.2$, and $50.7 \%$. The corresponding proportions of ryegrass in the sward (intended: 20\%) were $7.5,17.9,26.3$, and 17.7, and those of the weeds were 1.4, 13.2, 19.5, and 31.6. The green forages did not differ considerably in their proximate composition (Table 1). Changes in fiber and CP contents during the experimental feeding period were smaller in the flowering crops compared with chicory and ryegrass. The buckwheat sward had the highest DM content (1.5-fold higher than that of the chicory sward). The swards with flowering catch crops were lower in $\mathrm{CP}$ than swards with chicory and ryegrass, but ranged between these 2 control plants in NDF content. Lignification was higher in all dicots compared with the ryegrass. The same was true for the non-NDF carbohydrates. In all forages, 18:3 n-3 was the dominant FA (lowest in the buckwheat sward), followed by 18:2 n- 6 and 16:0. The proportion of 18:1 n-9 ranged from 20 (berseem clover sward) to almost $90 \mathrm{~g} / \mathrm{kg}$ (buckwheat sward). Among tocopherols, $\alpha$-tocopherol accounted for almost $90 \%$ (Table 2). The levels found in the swards with flowering catch crops lay within the range covered by ryegrass and chicory swards. The TEP content was highest in buckwheat and chicory swards and lowest in the ryegrass sward. The same order was found for the contents of TT and CT.

\section{Intake and Performance}

Intake of DM was lowest $(P<0.05)$ with the chicory diet, which also was reflected in intakes of $\mathrm{OM}$ and fiber (Table 3). Higher concentration of CP partially compensated the low DMI for this nutrient within the chicory treatment. Cows of the buckwheat group ingested the lowest amount of ether extract $(P<0.05)$. Because of the lower 18:3 n-3 concentration in the buckwheat diet, the intake difference to the other groups was even more pronounced for this particular FA $(P<0.05)$. Intake of 18:2 n-6 was highest $(P<0.05)$ with the phacelia diet (compared with berseem clover, chicory, and ryegrass), but did not differ among the other groups. Compared with the ryegrass diet, TEP intake was 2 -fold higher in the buckwheat group and 1.5-fold higher with the other treatments $(P<0.05)$.

All cows lost weight during the experiment, but changes in BW and BCS did not significantly differ among groups. Also, milk yield declined compared with the baseline period independently of treatment. Milk fat content was lower $(P<0.05)$ in the berseem clover treatment than in the buckwheat and phacelia groups. In the group fed the berseem clover sward, milk protein contents exceeded $(P<0.05)$ those found with chicory and ryegrass diets. Contents of $\beta-, \gamma-$, and $\delta$-tocopherols in milk were always below the detection limit, leaving $\alpha$-tocopherol as the only relevant form of vitamin E. Milk $\alpha$-tocopherol was highest in the buckwheat group, and almost as high with the ryegrass treatment, whereas it was clearly $(P<0.05)$ lower with berseem clover, phacelia, and chicory diets. In the baseline period, $\alpha$-tocopherol amounted to $936 \mu \mathrm{g} / \mathrm{kg}$ of milk on average. Concentration of TEP in milk was 1.4-fold higher in the chicory group compared with the ryegrass group, whereas concentrations in milk for the treatments with clover, buckwheat, and phacelia did not differ among each other. In the baseline period, milk contained 87.9 $\mathrm{mg}$ of $\mathrm{TEP} / \mathrm{kg}$ on average.

\section{Milk Fatty Acids}

The major part of the FA in milk fat was represented by the saturated FA, being on average 1.6 times higher in proportion than the monounsaturated FA and 12 times higher than the polyunsaturated FA (PUFA; Table 4). Cows fed berseem clover and phacelia diets produced milk fat with higher saturated FA and PUFA but lower monounsaturated FA proportions compared with the chicory diet $(P<0.05)$. However, individual FA and groups of FA within PUFA differed in their response to the feeding treatments. The proportion of total n-3 FA and of ALA was highest in the group fed the berseem clover diet (1.5-fold higher compared with the ryegrass group) followed by the groups fed the phacelia (1.4-fold), buckwheat, and the chicory diet (1.1-fold; $P<0.05)$. Proportions of the long-chain n-3 PUFA, 22:5n-3, were high with the phacelia compared with the buckwheat, the chicory, and the ryegrass treatment $(P$ $<0.05$ ), whereas the berseem clover treatment did not differ from the other treatments. The differences in the proportion of total n- $6 \mathrm{FA}$ in milk and its major representative, LA, were somewhat smaller in magnitude, with higher $(P<0.05)$ values found with the 2 flowering catch crop diets buckwheat and phacelia compared with chicory and ryegrass diets. The proportion of 20:4 n-6 in milk fat was increased $(P<0.05)$ with the berseem clover diet compared with all other groups.

Concerning the intermediates of ruminal biohydrogenation of LA found in milk fat, the $c 9, t 11$ 18:2 proportion was lowest in the buckwheat group $(P<0.05$; only different from the berseem clover group), which also was true for the coeluting peak of $t 10$ 18:1 and $t 11$ 18:1 
Table 1. Chemical composition of the experimental feeds

\begin{tabular}{|c|c|c|c|c|c|c|c|c|c|c|c|c|c|c|c|c|c|c|}
\hline \multirow[b]{3}{*}{ Item } & \multicolumn{15}{|c|}{ Experimental swards } & \multirow{2}{*}{\multicolumn{3}{|c|}{$\frac{\text { Supplemental feeds }}{\text { Concentrate }}$}} \\
\hline & \multicolumn{3}{|c|}{ Berseem clover } & \multicolumn{3}{|c|}{ Buckwheat } & \multicolumn{3}{|c|}{ Phacelia } & \multicolumn{3}{|c|}{ Chicory } & \multicolumn{3}{|c|}{ Ryegrass } & & & \\
\hline & Avg. ${ }^{1}$ & Start $^{2}$ & End $^{3}$ & Avg. & Start & End & Avg. & Start & End & Avg. & Start & End & Avg. & Start & End & Hay & Energy & Protein \\
\hline \multicolumn{19}{|l|}{$\begin{array}{l}\text { Proximate contents, } \\
\text { g/kg DM }\end{array}$} \\
\hline $\mathrm{DM}^{4}$ & 117 & 106 & 128 & 160 & 147 & 157 & 120 & 110 & 135 & 104 & 90 & 103 & 131 & 134 & 135 & 858 & 899 & 912 \\
\hline $\mathrm{OM}$ & 872 & 874 & 883 & 888 & 858 & 894 & 852 & 855 & 852 & 810 & 740 & 834 & 871 & 855 & 883 & 903 & 953 & 941 \\
\hline $\mathrm{CP}$ & 171 & 212 & 142 & 138 & 142 & 125 & 149 & 148 & 154 & 191 & 183 & 176 & 190 & 222 & 156 & 128 & 156 & 470 \\
\hline $\mathrm{NDF}$ & 432 & 414 & 463 & 502 & 478 & 516 & 469 & 469 & 476 & 401 & 339 & 465 & 560 & 469 & 602 & 510 & 251 & 142 \\
\hline $\mathrm{ADF}$ & 339 & 297 & 355 & 383 & 397 & 388 & 349 & 332 & 351 & 294 & 277 & 328 & 331 & 295 & 373 & 281 & 83 & 96 \\
\hline Acid detergent lignin & 70.3 & 62.3 & 82.5 & 82.6 & 73.1 & 98.6 & 83.5 & 93.9 & 73.4 & 74.6 & 48.7 & 90.5 & 49.2 & 36.3 & 82.7 & 31.9 & 25.5 & 12.2 \\
\hline $\begin{array}{l}\text { Non-NDF } \\
\text { carbohydrates }\end{array}$ & 227 & 196 & 239 & 202 & 187 & 213 & 192 & 195 & 185 & 161 & 162 & 150 & 78 & 104 & 89 & 215 & 483 & 304 \\
\hline Ether extract & 25.9 & 31.6 & 20.7 & 19.7 & 25.9 & 15.7 & 24.4 & 29.6 & 22.1 & 34.6 & 38.5 & 24.6 & 32.3 & 47.9 & 21.6 & 38.9 & 58.7 & 20.1 \\
\hline \multicolumn{19}{|l|}{$\begin{array}{l}\text { Fatty acids (FA), } \\
\mathrm{g} / \mathrm{kg} \text { total FAME }\end{array}$} \\
\hline $12: 0$ & 71.3 & 61.7 & 80.8 & 98.6 & 127.8 & 101.0 & 75.4 & 71.1 & 70.6 & 54.5 & 60.5 & 59.9 & 68.1 & 67.0 & 41.7 & 72.0 & 34.1 & 26.0 \\
\hline $14: 0$ & 32.2 & 32.2 & 30.1 & 23.9 & 24.4 & 23.4 & 26.9 & 24.7 & 27.9 & 33.7 & 34.2 & 35.9 & 41.5 & 41.7 & 43.0 & 32.3 & 5.5 & 26.2 \\
\hline $16: 0$ & 131 & 131 & 133 & 152 & 145 & 150 & 147 & 144 & 146 & 147 & 147 & 148 & 152 & 138 & 166 & 160 & 153 & 149 \\
\hline $16: 1$ & 43.4 & 44.4 & 39.4 & 30.8 & 34.9 & 28.4 & 31.8 & 30.2 & 29.1 & 40.2 & 36.3 & 46.4 & 43.6 & 35.6 & 58.3 & 39.2 & 5.2 & 0.0 \\
\hline $18: 0$ & 22.7 & 22.7 & 22.4 & $\mathrm{ND}^{5}$ & ND & $\mathrm{ND}$ & 13.6 & 12.8 & 13.4 & ND & ND & ND & 15.2 & 11.3 & 19.3 & 17.0 & 51.9 & 42.0 \\
\hline $18: 1 \mathrm{n}-9$ & 21.0 & 15.2 & 24.7 & 85.9 & 53.9 & 106.1 & 65.0 & 75.4 & 62.3 & 50.3 & 27.5 & 66.1 & 36.7 & 24.2 & 50.5 & 20.7 & 250.5 & 198.7 \\
\hline $18: 2 n-6$ & 179 & 162 & 196 & 256 & 231 & 276 & 236 & 252 & 229 & 225 & 204 & 255 & 173 & 138 & 193 & 155 & 458 & 502 \\
\hline $18: 3 n-3$ & 498 & 530 & 474 & 353 & 383 & 316 & 405 & 252 & 422 & 449 & 491 & 388 & 470 & 544 & 355 & 504 & 42 & 56 \\
\hline Saturated FA & 258 & 248 & 267 & 274 & 297 & 274 & 263 & 252 & 258 & 235 & 241 & 244 & 277 & 258 & 318 & 281 & 244 & 243 \\
\hline Monounsaturated FA & 65 & 60 & 64 & 117 & 89 & 134 & 97 & 106 & 91 & 90 & 64 & 112 & 80 & 60 & 109 & 60 & 256 & 199 \\
\hline Polyunsaturated FA & 678 & 692 & 670 & 609 & 614 & 591 & 641 & 642 & 651 & 674 & 695 & 644 & 642 & 682 & 573 & 659 & 500 & 558 \\
\hline
\end{tabular}

${ }^{1}$ Average over the experiment, with $\mathrm{n}=4$ for berseem clover, buckwheat, chicory, and ryegrass and $\mathrm{n}=3$ for phacelia.

${ }^{2}$ Start of the experimental feeding.

${ }^{3}$ End of the experimental feeding.

${ }^{4} \mathrm{~g} / \mathrm{kg}$ as fed.

${ }^{5}$ Not detected. 
Table 2. Tocopherol and phenol contents of the experimental feeds

\begin{tabular}{|c|c|c|c|c|c|c|c|c|c|c|c|c|c|c|c|c|c|c|}
\hline \multirow[b]{3}{*}{ Item } & \multicolumn{15}{|c|}{ Experimental swards } & \multirow{2}{*}{\multicolumn{3}{|c|}{$\begin{array}{r}\text { Supplemental feeds } \\
\text { Concentrate }\end{array}$}} \\
\hline & \multicolumn{3}{|c|}{ Berseem clover } & \multicolumn{3}{|c|}{ Buckwheat } & \multicolumn{3}{|c|}{ Phacelia } & \multicolumn{3}{|c|}{ Chicory } & \multicolumn{3}{|c|}{ Ryegrass } & & & \\
\hline & Avg. ${ }^{1}$ & Start $^{2}$ & End $^{3}$ & Avg. & Start & End & Avg. & Start & End & Avg. & Start & End & Avg. & Start & End & Hay & \multicolumn{2}{|c|}{ Energy Protein } \\
\hline \multicolumn{19}{|l|}{$\begin{array}{l}\text { Tocopherols, } \\
\mathrm{mg} / \mathrm{kg} \text { of DM }\end{array}$} \\
\hline Total & 5.72 & 6.78 & 5.57 & 4.76 & 4.49 & 4.07 & 5.47 & 5.96 & 5.32 & 6.60 & 5.53 & 5.49 & 4.73 & 4.84 & 3.74 & 4.42 & 3.81 & 3.72 \\
\hline$\alpha$-Tocopherol & 5.40 & 6.44 & 5.25 & 4.21 & 4.01 & 3.62 & 5.03 & 5.47 & 4.92 & 5.80 & 4.90 & 4.84 & 4.32 & 4.44 & 3.36 & 4.01 & 3.29 & 3.13 \\
\hline$\beta$-Tocopherol & 0.104 & 0.116 & 0.102 & 0.107 & 0.111 & 0.100 & 0.107 & 0.101 & 0.110 & 0.109 & 0.105 & 0.108 & 0.107 & 0.111 & 0.106 & 0.118 & 0.165 & 0.180 \\
\hline$\gamma$-Tocopherol & 0.140 & 0.161 & 0.143 & 0.365 & 0.303 & 0.274 & 0.251 & 0.320 & 0.220 & 0.614 & 0.462 & 0.466 & 0.230 & 0.212 & 0.206 & 0.211 & 0.287 & 0.336 \\
\hline$\delta$-Tocopherol & 0.071 & 0.067 & 0.077 & 0.072 & 0.066 & 0.075 & 0.074 & 0.073 & 0.078 & 0.076 & 0.072 & 0.073 & 0.075 & 0.076 & 0.070 & 0.073 & 0.068 & 0.070 \\
\hline \multicolumn{19}{|c|}{$\begin{array}{l}\text { Extractable } \\
\text { phenols, } \\
\mathrm{mg} / 100 \mathrm{~g} \text { of } \mathrm{DM}\end{array}$} \\
\hline Total $^{4}$ & 1,714 & 2,136 & 1,825 & 2,583 & 2,589 & 2,464 & 1,661 & 1,717 & 1,563 & 2,162 & 1,822 & 1,852 & 1,176 & 1,335 & 1,399 & 1,120 & 425 & 486 \\
\hline Non-tannin ${ }^{4}$ & 815 & 922 & 833 & 705 & 827 & 699 & 815 & 874 & 749 & 804 & 660 & 694 & 557 & 585 & 486 & 753 & 216 & 454 \\
\hline Total tannins ${ }^{4}$ & 899 & 1,214 & 992 & 1,879 & 1,762 & 1,765 & 846 & 842 & 813 & 1,357 & 1,161 & 1,159 & 619 & 750 & 913 & 367 & 208 & 32 \\
\hline $\begin{array}{l}\text { Condensed } \\
\text { tannins }^{5}\end{array}$ & 4 & $\mathrm{ND}^{6}$ & 7 & 326 & 276 & 369 & 50 & 70 & 58 & 124 & 67 & 82 & 27 & 20 & 46 & 4 & 0 & 0 \\
\hline
\end{tabular}

${ }^{1}$ Average over the experiment with $\mathrm{n}=4$ for berseem clover, buckwheat, chicory, and ryegrass and $\mathrm{n}=3$ for phacelia.

${ }^{2}$ Start of the experimental feeding.

$\quad{ }^{3}$ End of the experimental feeding.

$\stackrel{{ }^{4}}{\mathrm{E}}$ Expressed as gallic acid equivalents.

${ }^{5}$ Expressed as leukocyanidin equivalents.

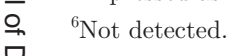


Table 3. Intake and performance for diets containing berseem clover $(\mathrm{n}=6)$, buckwheat $(\mathrm{n}=5)$, phacelia $(\mathrm{n}=6)$, chicory $(\mathrm{n}=6)$, and ryegrass $(\mathrm{n}=5)$

\begin{tabular}{|c|c|c|c|c|c|c|c|}
\hline Item & $\begin{array}{l}\text { Berseem } \\
\text { clover }\end{array}$ & Buckwheat & Phacelia & Chicory & Ryegrass & SEM & $P$-value \\
\hline \multicolumn{8}{|l|}{ Daily DM intake, ${ }^{1} \mathrm{~kg}$} \\
\hline Total & $17.8^{\mathrm{a}}$ & $16.4^{\mathrm{a}}$ & $17.4^{\mathrm{a}}$ & $13.4^{\mathrm{c}}$ & $15.6^{\mathrm{b}}$ & 0.53 & $<0.001$ \\
\hline Treatment forage & $13.1^{\mathrm{a}}$ & $12.6^{\mathrm{a}}$ & $12.7^{\mathrm{a}}$ & $9.6^{\mathrm{b}}$ & $11.8^{\mathrm{a}}$ & 0.53 & $<0.001$ \\
\hline \multicolumn{8}{|l|}{ Daily nutrient intake } \\
\hline $\mathrm{OM}, \mathrm{kg}$ & $15.7^{\mathrm{a}}$ & $14.9^{\mathrm{ab}}$ & $15.1^{\mathrm{ab}}$ & $11.5^{\mathrm{c}}$ & $13.9^{\mathrm{b}}$ & 0.46 & $<0.001$ \\
\hline $\mathrm{CP}, \mathrm{kg}$ & $2.98^{\mathrm{a}}$ & $2.54^{\mathrm{c}}$ & $2.86^{\mathrm{ab}}$ & $2.70^{\mathrm{bc}}$ & $2.94^{\mathrm{ab}}$ & 0.091 & 0.007 \\
\hline $\mathrm{NDF}, \mathrm{kg}$ & $7.56^{\mathrm{b}}$ & $7.82^{\mathrm{ab}}$ & $7.82^{\mathrm{ab}}$ & $5.40^{\mathrm{c}}$ & $8.36^{\mathrm{a}}$ & 0.259 & $<0.001$ \\
\hline Non-NDF carbohydrates, kg & $4.45^{\mathrm{a}}$ & $3.77^{\mathrm{b}}$ & $3.73^{\mathrm{b}}$ & $2.71^{\mathrm{c}}$ & $2.01^{\mathrm{d}}$ & 0.095 & $<0.001$ \\
\hline Ether extract, $g$ & $464^{\mathrm{a}}$ & $370^{\mathrm{b}}$ & $461^{\mathrm{a}}$ & $474^{\mathrm{a}}$ & $468^{\mathrm{a}}$ & 14.3 & $<0.001$ \\
\hline $18: 0, \mathrm{~g}$ & $11.8^{\mathrm{a}}$ & $4.9^{\mathrm{d}}$ & $9.0^{\mathrm{c}}$ & $4.9^{\mathrm{d}}$ & $9.6^{\mathrm{b}}$ & 0.14 & $<0.001$ \\
\hline $18: 1, \mathrm{~g}$ & $28.2^{\mathrm{e}}$ & $42.1^{\mathrm{a}}$ & $38.0^{\mathrm{b}}$ & $34.9^{\mathrm{c}}$ & $32.4^{\mathrm{d}}$ & 0.71 & $<0.001$ \\
\hline $18: 2 \mathrm{n}-6, \mathrm{~g}$ & $103^{\mathrm{b}}$ & $105^{\mathrm{ab}}$ & $112^{\mathrm{a}}$ & $103^{\mathrm{b}}$ & $99^{\mathrm{b}}$ & 2.6 & 0.020 \\
\hline $18: 3 \mathrm{n}-3, \mathrm{~g}$ & $175^{\mathrm{a}}$ & $100^{\mathrm{d}}$ & $147^{\mathrm{bc}}$ & $134^{\mathrm{c}}$ & $159^{\mathrm{b}}$ & 5.4 & $<0.001$ \\
\hline Saturated FA, ${ }^{2} \mathrm{~g}$ & $113^{\mathrm{a}}$ & $91^{\mathrm{b}}$ & $109^{\mathrm{a}}$ & $90^{\mathrm{b}}$ & $113^{\mathrm{a}}$ & 3.1 & $<0.001$ \\
\hline Monounsaturated FA, g & $43^{\mathrm{c}}$ & $50^{\mathrm{a}}$ & $49^{\mathrm{ab}}$ & $47^{\mathrm{b}}$ & $47^{\mathrm{ab}}$ & 1.1 & $<0.001$ \\
\hline Polyunsaturated FA, g & $279^{\mathrm{a}}$ & $205^{\mathrm{c}}$ & $259^{\mathrm{a}}$ & $237^{\mathrm{b}}$ & $258^{\mathrm{ab}}$ & 8.0 & $<0.001$ \\
\hline$\alpha$-Tocopherol, ${ }^{3} \mathrm{mg}$ & $331^{\mathrm{a}}$ & $315^{\mathrm{cd}}$ & $327^{\mathrm{ab}}$ & $321^{\text {bc }}$ & $312^{\mathrm{d}}$ & 2.8 & $<0.001$ \\
\hline Total phenols, ${ }^{4} \mathrm{~g}$ & $246^{\mathrm{b}}$ & $356^{\mathrm{a}}$ & $244^{\mathrm{b}}$ & $252^{\mathrm{b}}$ & $162^{\mathrm{c}}$ & 10.9 & $<0.001$ \\
\hline \multicolumn{8}{|l|}{ Performance } \\
\hline BW change, kg & -22.3 & -41.8 & -43.9 & -43.4 & -29.9 & 10.95 & 0.53 \\
\hline BCS change, grades & -0.083 & -0.100 & -0.083 & -0.000 & -0.100 & 0.1191 & 0.97 \\
\hline $\mathrm{ECM}, \mathrm{kg} / \mathrm{d}$ & $21.9^{\mathrm{a}}$ & $20.5^{\mathrm{ab}}$ & $21.4^{\mathrm{ab}}$ & $19.7^{\mathrm{b}}$ & $20.5^{\mathrm{ab}}$ & 0.72 & 0.23 \\
\hline \multicolumn{8}{|l|}{ Milk composition } \\
\hline Fat, \% & $4.24^{\mathrm{b}}$ & $4.80^{\mathrm{a}}$ & $4.82^{\mathrm{a}}$ & $4.61^{\mathrm{ab}}$ & $4.55^{\mathrm{ab}}$ & 0.141 & 0.028 \\
\hline Protein, \% & $3.39^{\mathrm{a}}$ & $3.37^{\mathrm{ab}}$ & $3.24^{\mathrm{abc}}$ & $3.18^{\mathrm{bc}}$ & $3.16^{\mathrm{c}}$ & 0.070 & 0.076 \\
\hline Lactose, \% & 4.67 & 4.61 & 4.63 & 4.65 & 4.65 & 0.032 & 0.73 \\
\hline$\alpha$-Tocopherol, ${ }^{5} \mu \mathrm{g} / \mathrm{kg}$ & $951^{\mathrm{b}}$ & $1,232^{\mathrm{a}}$ & $971^{\mathrm{b}}$ & $1,029^{\mathrm{b}}$ & $1,103^{\mathrm{ab}}$ & 65.9 & 0.026 \\
\hline Total phenols, ${ }^{4} \mathrm{mg} / \mathrm{kg}$ & $74.2^{\mathrm{b}}$ & $81.3^{\mathrm{ab}}$ & $69.0^{\mathrm{b}}$ & $93.1^{\mathrm{a}}$ & $66.0^{\mathrm{b}}$ & 5.83 & 0.010 \\
\hline
\end{tabular}

${ }^{\mathrm{a}-\mathrm{e}}$ Means within a row without a common superscript differ at $P<0.05$.

${ }^{1}$ Fixed offers of 2.7 (berseem clover, phacelia) and 1.9 (buckwheat, chicory, ryegrass) $\mathrm{kg}$ of ryegrass hay DM/d and $1.8 \mathrm{~kg}$ of concentrate $\mathrm{DM} / \mathrm{d}$.

${ }^{2}$ Fatty acids.

${ }^{3}$ From forage, concentrates, and mineral-vitamin mix.

${ }^{4}$ Expressed as gallic acid equivalents.

${ }^{5}$ No other form of tocopherol detected.

$(P<0.05$ relative to the phacelia and ryegrass groups). Nevertheless, 18:0 in milk fat from the buckwheat group was highest $(P<0.05$ against berseem clover and phacelia treatments). The main products of ALA biohydrogenation, $t 11, c 15$ 18:2 (coeluting with $t 9, c 12$ 18:2) and $t 11, c 1318: 2$, were highest in milk from cows fed the berseem clover and the phacelia diets and lowest with the buckwheat treatment $(P<0.05)$. Both ALA and LA proportions, and those of the corresponding intermediates of biohydrogenation mentioned above, were clearly increased in all groups compared with the baseline period and did not change significantly with time during the experiment (Figure 1). With few exceptions, treatment differences persisted throughout the 3 subperiods.

The concentrations of branched-chain FA in the milk fat, which are mostly of rumen microbial origin, were higher $(P<0.05)$ in milk fat derived from cows fed the berseem clover, phacelia, and ryegrass diets compared with that from cows fed buckwheat and chicory diets.

\section{Transfer Rates from Feed to Milk}

The ratio of ALA secreted with milk, relative to ALA ingested, was lowest when feeding the ryegrass $\operatorname{diet}(P<0.05$; except for chicory and berseem clover treatments), whereas it was highest $(P<0.05)$ with the buckwheat diet (Table 5). Related to intake, the secretion of LA in milk was higher $(P<0.05)$ in the group fed the buckwheat diet compared with cows fed ryegrass. No effect of treatment was detected for the ratio of $\alpha$-tocopherol secretion to $\alpha$-tocopherol intake.

\section{DISCUSSION}

The present study focused on the main hypothesis that flowering plants have a comparably larger inhibitory effect on biohydrogenation in the rumen than nonflowering plants (Cabiddu et al., 2005; Leiber et al., 2005), which was based on the fact that plants in blossom contain more secondary metabolites (del Baño 
Table 4. Fatty acids (FA) in milk fat ( $\mathrm{g} / \mathrm{kg}$ of total fatty acid methyl esters) for diets containing berseem clover $(\mathrm{n}=6)$, buckwheat $(\mathrm{n}=5)$, phacelia $(\mathrm{n}=6)$, chicory $(\mathrm{n}=6)$, and ryegrass $(\mathrm{n}=5)$

\begin{tabular}{|c|c|c|c|c|c|c|c|}
\hline FA & $\begin{array}{c}\text { Berseem } \\
\text { clover }\end{array}$ & Buckwheat & Phacelia & Chicory & Ryegrass & SEM & $P$-value \\
\hline 4:0 & $14.1^{\mathrm{ab}}$ & $15.2^{\mathrm{a}}$ & $13.1^{\mathrm{b}}$ & $12.9^{\mathrm{b}}$ & $14.6^{\mathrm{ab}}$ & 0.73 & 0.14 \\
\hline $6: 0$ & $28.4^{\mathrm{a}}$ & $23.4^{\mathrm{b}}$ & $26.9^{\mathrm{ab}}$ & $26.4^{\mathrm{ab}}$ & $27.6^{\mathrm{ab}}$ & 1.51 & 0.21 \\
\hline $8: 0$ & $15.4^{\mathrm{a}}$ & $13.54^{\mathrm{b}}$ & $14.0^{\mathrm{b}}$ & $13.6^{\mathrm{b}}$ & $13.3^{\mathrm{b}}$ & 0.49 & 0.02 \\
\hline $10: 0$ & $19.8^{\mathrm{a}}$ & $16.1^{\mathrm{c}}$ & $18.9^{\mathrm{ab}}$ & $17.0^{\mathrm{bc}}$ & $17.3^{\mathrm{abc}}$ & 0.98 & 0.05 \\
\hline $12: 0$ & $21.7^{\mathrm{a}}$ & $17.7^{\mathrm{b}}$ & $20.6^{\mathrm{ab}}$ & $18.4^{\mathrm{b}}$ & $18.9^{\mathrm{ab}}$ & 1.11 & 0.07 \\
\hline $14: 0$ & $86.5^{\mathrm{a}}$ & $73.9^{\mathrm{b}}$ & $82.0^{\mathrm{ab}}$ & $75.2^{\mathrm{b}}$ & $78.3^{\mathrm{ab}}$ & 2.91 & 0.02 \\
\hline $14: 0$ iso & $2.34^{\mathrm{a}}$ & $1.73^{\mathrm{c}}$ & $2.11^{\mathrm{b}}$ & $1.76^{\mathrm{c}}$ & $2.28^{\mathrm{ab}}$ & 0.082 & $<0.001$ \\
\hline 14:0 anteiso & $3.92^{\mathrm{ab}}$ & $3.63^{\mathrm{ab}}$ & $3.81^{\mathrm{ab}}$ & $3.42^{\mathrm{b}}$ & $4.17^{\mathrm{a}}$ & 0.198 & 0.12 \\
\hline $14: 1$ cis & $8.40^{\mathrm{a}}$ & $6.06^{\mathrm{c}}$ & $6.71^{\mathrm{bc}}$ & $6.28^{\mathrm{c}}$ & $7.38^{\mathrm{b}}$ & 0.297 & $<0.001$ \\
\hline $15: 0$ & $12.1^{\mathrm{a}}$ & $10.2^{\mathrm{b}}$ & $10.6^{\mathrm{b}}$ & $9.65^{\mathrm{b}}$ & $12.1^{\mathrm{a}}$ & 0.390 & $<0.001$ \\
\hline $15: 0$ iso & $2.72^{\mathrm{ab}}$ & $2.58^{\mathrm{ab}}$ & $2.81^{\mathrm{a}}$ & $2.50^{\mathrm{b}}$ & $2.80^{\mathrm{a}}$ & 0.088 & 0.049 \\
\hline $16: 0$ & $272^{\mathrm{a}}$ & $264^{\mathrm{ab}}$ & $270^{\mathrm{a}}$ & $261^{\mathrm{b}}$ & $264^{\mathrm{ab}}$ & 2.9 & 0.050 \\
\hline $16: 0$ iso & $5.60^{\mathrm{a}}$ & $4.70^{\mathrm{d}}$ & $5.09^{\mathrm{bc}}$ & $4.91^{\mathrm{cd}}$ & $5.44^{\mathrm{ab}}$ & 0.138 & $<0.001$ \\
\hline 16:0 anteiso & $2.13^{\mathrm{a}}$ & $2.20^{\mathrm{a}}$ & $2.02^{\mathrm{ab}}$ & $1.94^{\mathrm{ab}}$ & $1.81^{\mathrm{b}}$ & 0.102 & 0.09 \\
\hline $16: 1$ & 20.5 & 23.6 & 23.2 & 23.0 & 23.1 & 1.09 & 0.27 \\
\hline $17: 0$ & 7.96 & 7.79 & 8.03 & 7.86 & 8.09 & 0.180 & 0.79 \\
\hline $17: 0$ iso & $0.76^{\mathrm{c}}$ & $0.88^{\mathrm{bc}}$ & $1.09^{\mathrm{a}}$ & $0.96^{\mathrm{b}}$ & $0.85^{\mathrm{bc}}$ & 0.043 & $<0.001$ \\
\hline 17:0 anteiso & $3.83^{\mathrm{b}}$ & $4.33^{\mathrm{a}}$ & $4.48^{\mathrm{a}}$ & $4.25^{\mathrm{ab}}$ & $4.29^{\mathrm{ab}}$ & 0.173 & 0.09 \\
\hline 18:0 & $102^{\mathrm{c}}$ & $119^{\mathrm{a}}$ & $106^{\mathrm{bc}}$ & $115^{\mathrm{a}}$ & $113^{\mathrm{ab}}$ & 3.0 & $<0.001$ \\
\hline 18:1 trans -9 & $2.86^{\mathrm{a}}$ & $2.49^{\mathrm{b}}$ & $2.65^{\mathrm{ab}}$ & $2.50^{\mathrm{b}}$ & $2.65^{\mathrm{ab}}$ & 0.117 & 0.17 \\
\hline $18: 1$ trans $-10+$ trans -11 & $22.6^{\mathrm{ab}}$ & $19.4^{\mathrm{b}}$ & $23.8^{\mathrm{a}}$ & $22.1^{\mathrm{ab}}$ & $23.4^{\mathrm{a}}$ & 1.19 & 0.11 \\
\hline $18: 1$ trans -12 & $0.61^{\mathrm{a}}$ & $0.26^{\mathrm{ab}}$ & $0.19^{\mathrm{ab}}$ & $0.06^{\mathrm{b}}$ & $0.23^{\mathrm{ab}}$ & 0.173 & 0.22 \\
\hline $18: 1$ cis-9 & $278^{\mathrm{b}}$ & $308^{\mathrm{a}}$ & $281^{\mathrm{b}}$ & $310^{\mathrm{a}}$ & $300^{\mathrm{b}}$ & 6.2 & $<0.001$ \\
\hline $18: 1$ cis-11 & 5.74 & 4.78 & 5.46 & 5.83 & 5.69 & 0.518 & 0.64 \\
\hline $18: 1$ cis-12 & 4.27 & 3.88 & 4.42 & 4.21 & 3.92 & 0.229 & 0.41 \\
\hline $18: 1$ cis- 13 & $2.61^{\mathrm{a}}$ & $2.18^{\mathrm{b}}$ & $2.56^{\mathrm{a}}$ & $2.28^{\mathrm{ab}}$ & $2.42^{\mathrm{ab}}$ & 0.130 & 0.10 \\
\hline $18: 2 n-6$ & $20.3^{\mathrm{bc}}$ & $21.6^{\mathrm{a}}$ & $20.8^{\mathrm{ab}}$ & $19.4^{\mathrm{c}}$ & $16.4^{\mathrm{d}}$ & 0.435 & $<0.001$ \\
\hline 18:2 trans- 11 , cis- 13 & $0.71^{\mathrm{ab}}$ & $0.46^{\mathrm{c}}$ & $0.88^{\mathrm{a}}$ & $0.57^{\mathrm{bc}}$ & $0.58^{\mathrm{bc}}$ & 0.069 & $<0.001$ \\
\hline $18: 2$ trans -11, cis $-15+$ trans -9 , cis -12 & $4.35^{\mathrm{a}}$ & $2.20^{\mathrm{d}}$ & $3.82^{\mathrm{b}}$ & $2.91^{\mathrm{c}}$ & $3.17^{\mathrm{c}}$ & 0.166 & $<0.001$ \\
\hline $18: 2$ cis -9, trans -11 & $9.81^{\mathrm{a}}$ & $7.86^{\mathrm{b}}$ & $9.22^{\mathrm{ab}}$ & $9.40^{\mathrm{ab}}$ & $9.63^{\mathrm{ab}}$ & 0.599 & 0.218 \\
\hline $18: 3 n-3$ & $12.57^{\mathrm{a}}$ & $9.39^{\mathrm{c}}$ & $11.15^{\mathrm{b}}$ & $9.62^{\mathrm{c}}$ & $7.91^{\mathrm{d}}$ & 0.285 & $<0.001$ \\
\hline $20: 0$ & $0.99^{\mathrm{c}}$ & $1.39^{\mathrm{a}}$ & $1.17^{\mathrm{b}}$ & $1.16^{\mathrm{b}}$ & $1.17^{\mathrm{b}}$ & 0.046 & $<0.001$ \\
\hline $20: 4 n-6$ & $0.32^{\mathrm{a}}$ & $0.10^{\mathrm{b}}$ & $0.18^{\mathrm{b}}$ & $0.16^{\mathrm{b}}$ & $0.10^{\mathrm{b}}$ & 0.046 & 0.006 \\
\hline $20: 5 \mathrm{n}-3$ & $0.35^{\mathrm{b}}$ & $0.37^{\mathrm{b}}$ & $0.58^{\mathrm{a}}$ & $0.49^{\mathrm{ab}}$ & $0.43^{\mathrm{b}}$ & 0.052 & 0.029 \\
\hline $22: 0$ & $0.22^{\mathrm{a}}$ & $0.06^{\mathrm{b}}$ & $0.13^{\mathrm{ab}}$ & $0.19^{\mathrm{ab}}$ & $0.15^{\mathrm{ab}}$ & 0.049 & 0.24 \\
\hline $22: 5 \mathrm{n}-3$ & $0.73^{\mathrm{ab}}$ & $0.62^{\mathrm{b}}$ & $0.86^{\mathrm{a}}$ & $0.67^{\mathrm{b}}$ & $0.64^{\mathrm{b}}$ & 0.057 & 0.023 \\
\hline $22: 6 \mathrm{n}-3$ & $0.33^{\mathrm{ab}}$ & $0.21^{\mathrm{b}}$ & $0.42^{\mathrm{a}}$ & $0.30^{\mathrm{ab}}$ & $0.39^{\mathrm{a}}$ & 0.059 & 0.12 \\
\hline Saturated FA & $599^{\mathrm{a}}$ & $583^{\mathrm{ab}}$ & $598^{\mathrm{a}}$ & $578^{\mathrm{b}}$ & $588^{\mathrm{ab}}$ & 5.7 & 0.035 \\
\hline Monounsaturated FA & $347^{\mathrm{b}}$ & $371^{\mathrm{a}}$ & $350^{\mathrm{b}}$ & $375^{\mathrm{a}}$ & $369^{\mathrm{ab}}$ & 6.0 & 0.002 \\
\hline Polyunsaturated $\mathrm{FA}^{1}$ & $54.5^{\mathrm{a}}$ & $46.8^{\mathrm{bc}}$ & $52.1^{\mathrm{a}}$ & $47.0^{\mathrm{b}}$ & $43.1^{\mathrm{c}}$ & 1.27 & $<0.001$ \\
\hline Branched-chain FA & $21.3^{\mathrm{a}}$ & $20.0^{\mathrm{b}}$ & $21.2^{\mathrm{a}}$ & $19.9^{\mathrm{b}}$ & $21.6^{\mathrm{a}}$ & 0.42 & 0.012 \\
\hline Total n-3 & $14.3^{\mathrm{a}}$ & $10.7^{\mathrm{c}}$ & $12.8^{\mathrm{b}}$ & $10.9^{\mathrm{c}}$ & $9.3^{\mathrm{d}}$ & 0.33 & $<0.001$ \\
\hline Total n-6 & $20.6^{\mathrm{ab}}$ & $21.7^{\mathrm{a}}$ & $21.0^{\mathrm{a}}$ & $19.5^{\mathrm{b}}$ & $16.5^{\mathrm{c}}$ & 0.44 & $<0.001$ \\
\hline
\end{tabular}

${ }^{\mathrm{a}-\mathrm{d}}$ Means within a row without a common superscript differ at $P<0.05$.

${ }^{1}$ Contains traces of unidentified 18:2 isomers not separately displayed in the table.

et al., 2003; Sood and Nagar, 2003). The latter are known to have inhibitory effects on ruminal biohydrogenation activity (Khiaosa-Ard et al., 2009; Cabiddu et al., 2010), although this cannot be generalized for all secondary plant metabolites (Lourenço et al., 2008; Benchaar and Chouinard, 2009). The assumption followed by the current study was that the inclusion of considerable proportions of different flowering dicots in the dairy cow diets would shift the milk fatty acid profile toward higher proportions of ALA and long-chain PUFA. This expectation was matched by the results, but not for all tested catch crop plants based on the assumed increase of ALA transfer from feed to milk, as will be discussed further on.

\section{Effects on Milk Fatty Acid Profile}

The ALA content of the berseem clover sward ranged within values published for white and red clover (van Dorland et al., 2008) as well as crimson clover (Cabiddu et al., 2010) and corresponded to findings of Tyagi et al. (2009). Milk fat produced by the cows of the berseem clover group contained higher ALA concentrations compared with all other groups. The value was in the range of alpine milk (Leiber et al., 2005; Falchero et al., 2010), but somewhat lower than milk derived from cows fed red clover silage (Dewhurst et al., 2006). The rate of ALA transfer from feed to milk in the case of the berseem clover treatment was the same as that 
$18: 2 \mathrm{n}-6$

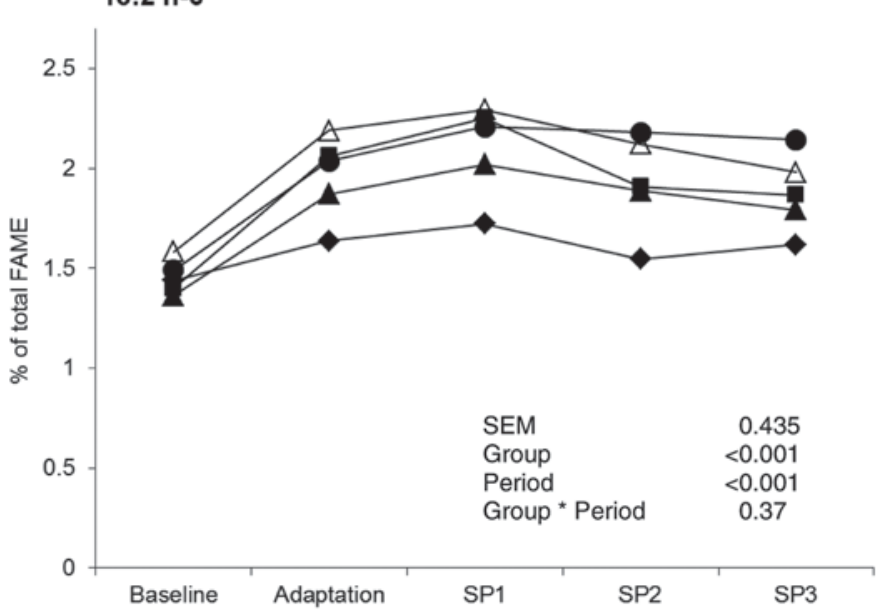

$18: 2 c 9, t 11$



18:1 $t 10+t 11$

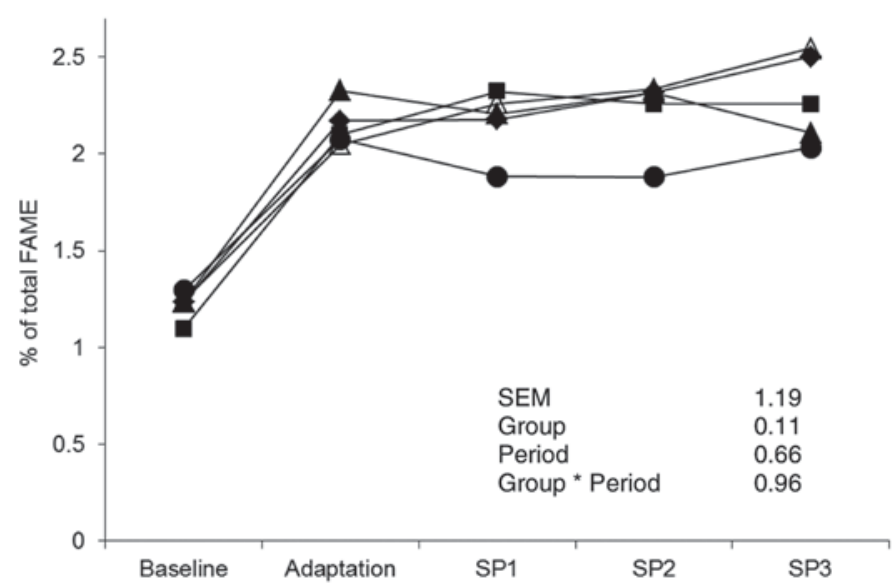

$18: 3 n-3$

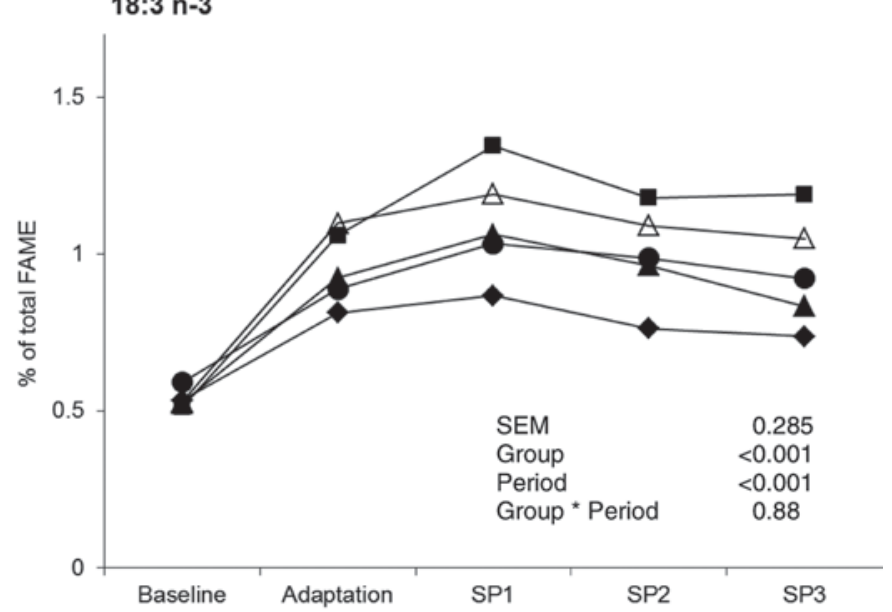

$18: 2 t 11, c 15+t 9, c 12$

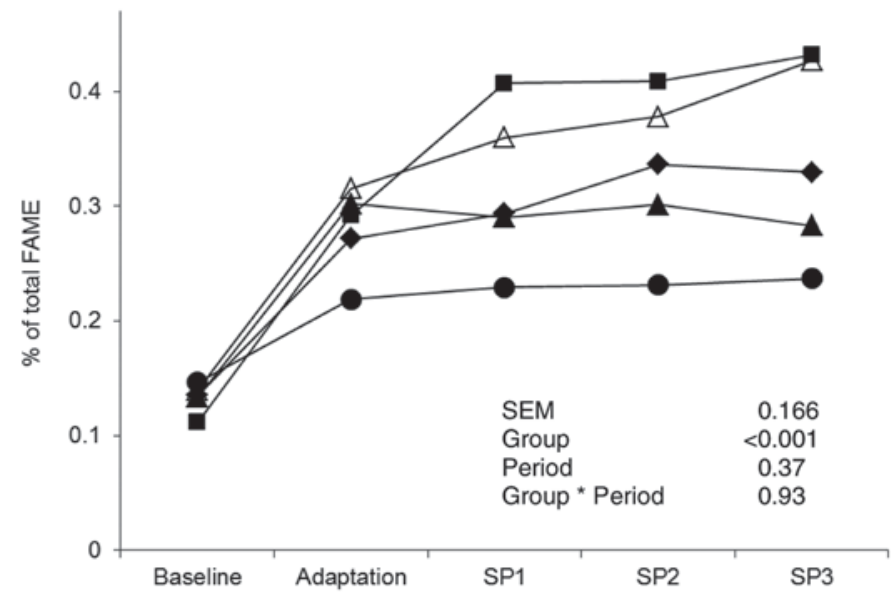

$18: 2 t 11, c 13$

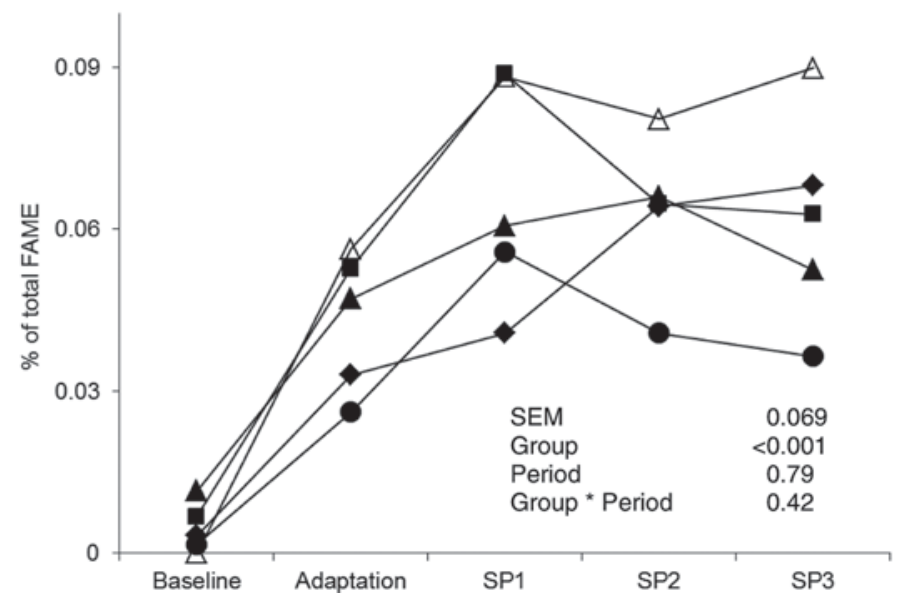

Figure 1. Evolution of milk fat proportions of linoleic acid and $\alpha$-linolenic acid and their most important biohydrogenation products over time beginning in the baseline period (baseline) and ending in the experimental period (SP) 3. Treatments: berseem clover ( $\mathbf{\square})$, buckwheat $(\bullet)$, phacelia $(\boldsymbol{\Lambda})$, chicory $(\Delta)$, and ryegrass $(\bullet)$. Values are means for each period $(\mathrm{n}=6$ for berseem clover, phacelia, and chicory; $\mathrm{n}=5$ for buckwheat and ryegrass). $t=$ trans; $c=$ cis. 
Table 5. Recovery rate of ingested linolenic and linoleic acid and $\alpha$-tocopherol in milk for diets containing berseem clover $(\mathrm{n}=6)$, buckwheat $(\mathrm{n}=5)$, phacelia $(\mathrm{n}=6)$, chicory $(\mathrm{n}=6)$, and ryegrass $(\mathrm{n}=5)$

\begin{tabular}{lccccccc}
\hline Item & $\begin{array}{c}\text { Berseem } \\
\text { clover }\end{array}$ & Buckwheat & Phacelia & Chicory & Ryegrass & SEM & $P$-value \\
\hline $18: 3 \mathrm{n}-3$ & $0.063^{\mathrm{bc}}$ & $0.093^{\mathrm{a}}$ & $0.068^{\mathrm{b}}$ & $0.059^{\mathrm{bc}}$ & $0.045^{\mathrm{c}}$ & 0.0068 & $<0.001$ \\
$18: 2 \mathrm{n}-6$ & $0.174^{\mathrm{ab}}$ & $0.199^{\mathrm{a}}$ & $0.174^{\mathrm{ab}}$ & $0.150^{\mathrm{ab}}$ & $0.136^{\mathrm{b}}$ & 0.0182 & 0.18 \\
$\alpha$-Tocopherol & 0.065 & 0.072 & 0.070 & 0.058 & 0.067 & 0.0069 & 0.58 \\
\hline
\end{tabular}

${ }^{\mathrm{a}-\mathrm{c}}$ Means within a row without a common superscript differ at $P<0.05$.

published by van Dorland et al. (2008) for a red clover diet. Still, the comparably large peak in the chromatogram containing 18:2 $t 11, c 15$ in milk fat of the berseem clover group indicates a high biohydrogenation rate because this isomer is one of the main intermediates of ruminal ALA transformation (Chilliard et al., 2007). It appears that the high ALA concentration in milk fat of the berseem clover group was mainly realized through a higher ALA intake and only partly by an increased transfer rate compared with the ryegrass group. Also, the transfer of LA was scarcely increased in the berseem clover group compared with the ryegrass and the nonflowering chicory groups. Therefore, the main hypothesis of this study was not clearly verified for the berseem clover treatment, which might be due to the fact that the berseem clover sward was the representative of the flowering catch crops with the lowest TEP content. For the phacelia diet, the result was similar: its feeding resulted in similar ALA and TEP intake rates as the berseem clover diet, and this was again accompanied by comparably high ALA concentrations in milk fat, which also were not obviously the result of an increased ALA transfer rate.

The clearest support of the main hypothesis was found with the buckwheat group, although it did not result in particularly high ALA concentrations. Here, the daily intake of TEP was highest, the intermediates of ALA biohydrogenation found in milk fat were lowest, and ALA transfer was most efficient. The high extractable phenol content expressed in the buckwheat sward had been expected as buckwheat is well examined as a functional food ( $\mathrm{Li}$ and Zhang, 2001) and pharmacological plant (Hinneburg et al., 2006) due to its concentrations of plant secondary compounds (Wijngaard and Arendt, 2006). But unexpectedly, the buckwheat sward contained particularly high amounts of tannins. Literature provides preliminary evidence for the inhibiting effect of such compounds on biohydrogenating activity in the rumen (Khiaosa-Ard et al., 2009; Cabiddu et al., 2010). The fact that the important ALA biohydrogenation intermediates 18:2 t11,c15 and 18:2 $t 11, c 13$ (Chilliard et al., 2007) were reduced in milk fat of the buckwheat group suggests an actual inhibition of ruminal ALA saturation and thus provides a possible explanation for the enhanced ALA transfer rate that was 2-fold higher than in the ryegrass treatment. Further, the intermediates of LA biohydrogenation (18:2 $c 9, t 11$ and $18: 1 t 10+t 11)$ in milk fat were lower than with all other plants, which also indicates inhibitory effects on ruminal lipid saturation. Finally, the slightly lower concentrations of branched-chain FA in the buckwheat group also suggest inhibited microbial activity in the rumen (Vlaeminck et al., 2006).

It has to be stated, however, that due to its design, this study does not allow us to make a direct link between any specific plant secondary compound and distinct ruminal microbe strains. Many other foragebound factors are involved in biohydrogenation and FA transfer as well. Fiber and soluble carbohydrate proportions are likely to be important, and the higher intakes of non-NDF carbohydrates with all flowering treatments compared with chicory and particularly to ryegrass also could have played a role in ALA recovery (Scollan et al., 2003). Higher dietary lignin may result in an accumulation of ALA and RA ( $\mathrm{Li}$ and Meng, 2006). In the current experiment, RA concentrations in milk fat increased with time, reflecting increasing lignification, but ALA concentrations did not. A further possible factor for the differences found in ALA transfer could have been the result of a compensatory effect at low ALA intake (Khiaosa-ard et al., 2010).

Compared with the controls, the positive effect on ALA concentration in milk fat was associated with higher 20:5 n-3 and 22:5 n-3 levels only with the phacelia treatment. This type of response had previously been reported for alpine sward grazing and ryegrass hay compared with concentrate-based diets (Leiber et al., 2005; Khiaosa-Ard et al., 2010). The reason for the lack of effects on the long-chain n-3 PUFA in milk fat of the berseem clover group is not clear. However, the efficiency of chain elongation is low and decreases with every step (Pawlosky et al., 2001), causing a stepwise dilution of effects on ALA. This might explain the lack of change in 22:6 n-3 concentrations even with the phacelia treatment.

\section{Effects on Tocopherols in Milk}

The $\alpha$-tocopherol concentrations found in milk fat were in the range of the values reported by Butler et 
al. (2008) for a diet mainly based on ryegrass. However, no treatment effects occurred although these had been expected as Havemose et al. (2006) described that the transfer of $\alpha$-tocopherol from feed to milk might be associated with higher ALA and LA concentrations in milk fat. This was not the case for the treatment with the highest ALA level, berseem clover, compared with the other treatments. The daily secretion of $\alpha$-tocopherol with milk was even rather low in the berseem clover group, reaching only the lower physiological threshold reported by Jensen et al. (1999). Our findings are rather in agreement with Nozière et al. (2006) who showed that vitamin E secretion into milk is constant although plasma concentrations may fluctuate reciprocal to PUFA intake (Chikunya et al., 2004). Apart from an effect of the PUFA, the high antioxidant activity of different buckwheat metabolites (Oomah and Mazza, 1996; Watanabe, 1998; Hinneburg et al., 2006) had been expected to save tocopherols and thus to facilitate the carryover of the latter into milk. This was not the case in the present study as seen from the unchanged $\alpha$-tocopherol carryover.

\section{Utility of the Catch Crops as Forages}

The fact that DMI and milk yield were similar in all flowering catch crop groups indicates that these forages were not clearly inferior to ryegrass, which was unexpected as, unlike ryegrass, these plants have not been specifically selected for high feeding value. Losses of BW and BCS during the experiment were marginal and milk composition did not show distinct signs of nutrient imbalance. Corresponding with data published for sheep (Sims et al., 1991), feeding the berseem clover sward did not cause bloat in the cows although it was fed at high dietary proportions. Within the buckwheat group, no symptoms of photosensitization (Mulholland and Coombe, 1979) occurred. Although low in CP, the use of buckwheat as a dietary component did not impair performance, which indicates that $\mathrm{N}$ utilization is favorable (Amelchanka et al., 2010). Finally, the insertion of phacelia in the diet proved to be suitable even though Scheller (1981) had claimed that this plant should not be recommended as a forage for dairy cows.

\section{CONCLUSIONS}

All test swards resulted in a major nutrients composition comparable to ryegrass except for the $\mathrm{CP}$ content of buckwheat and phacelia. No impaired feed intake or performance was observed in comparison with the ryegrass treatment, which indicates an equivalence of these forages in practical feeding. Both the berseem clover and the phacelia feeding regimen led to enhanced concentrations of ALA and LA in milk fat, which mainly referred to the increased intake of these 2 fatty acids with the feed. In contrast, it was found that metabolites in the buckwheat diet seem to have an inhibitory effect on ruminal biohydrogenation of ALA and thus enhance the transfer of the latter from feed to milk. This effect could not be related to a certain fraction of phenols, although it seemed that tannins could play a role in this context. Hence further research should be done on the effect of individual phenolic compounds on biohydrogenation.

\section{ACKNOWLEDGMENTS}

The authors gratefully acknowledge the project support provided by the Swiss Grassland Society (AGFF; Zurich) and the Fenaco UFA Samen (Sursee, Switzerland). The authors want to thank H.-R. Wettstein and the staff of the ETH Research Station Chamau for their assistance and support during the experiment and C. Kunz and the laboratory staff for their help with the analyses.

\section{REFERENCES}

ALP (Agroscope Liebefeld-Posieux). 2008. Feeding Recommendations and Nutrient Tables (In German). Online version. Accessed on July 5, 2010. http://www.agroscope.admin.ch/ praxis $/ 00215 / 00801 / 01587 /$ index.html?lang=de.

Amelchanka, S. L., M. Kreuzer, and F. Leiber. 2010. Utility of buckwheat (Fagopyrum esculentum Moench) as feed: Effects of forage and grain on in vitro ruminal fermentation and performance of dairy cows. Anim. Feed Sci. Technol. 155:111-121.

AOAC. 1997. Official Methods of Analysis. Assoc. Off. Anal. Chem., Arlington, VA.

Benchaar, C., and P. Y. Chouinard. 2009. Assessment of the potential of cinnamaldehyde, condensed tannins, and saponins to modify milk fatty acid composition of dairy cows. J. Dairy Sci. 92:33923396.

Butler, G., J. H. Nielsen, T. Slots, C. Seal, M. D. Eyre, R. Sanderson, and C. Leifert. 2008. Fatty acid and fat-soluble antioxidant concentrations in milk from high- and low-input conventional and organic systems: seasonal variation. J. Sci. Food Agric. 88:1431-1441.

Cabiddu, A., M. Decandia, M. Addis, G. Piredda, A. Pirisi, and G. Molle. 2005. Managing Mediterranean pastures in order to enhance the level of beneficial fatty acids in sheep milk. Small Rumin. Res. 59:169-180.

Cabiddu, A., L. Salis, J. K. S. Tweed, G. Molle, M. Decandia, and M. R. F. Lee. 2010. The influence of plant polyphenols on lipolysis and biohydrogenation in dried forages at different phenological stages: In vitro study. J. Sci. Food Agric. 90:829-835.

Chikunya, S., G. Demirel, M. Enser, J. D. Wood, R. G. Wilkinson, and L. A. Sinclair. 2004. Biohydrogenation of dietary n-3 PUFA and stability of ingested vitamin $\mathrm{E}$ in the rumen, and their effects on microbial activity in sheep. Br. J. Nutr. 91:539-550.

Chilliard, Y., F. Glasser, A. Ferlay, L. Bernard, J. Roul, and M. Doreau. 2007. Diet, rumen biohydrogenation and nutritional quality of cow and goat milk fat. Eur. J. Lipid Sci. Technol. 109:828-855.

Collomb, M., and B. Bühler. 2000. Analyse de la composition en acides gras de la graisse de lait. Mitt. Lebensm. Hyg. 91:306-332.

Daniel, P., and U. Zobelt. 1986. Untersuchungen über die Futteraufnahme von Futterraps (Brassica napus L.) und Phazelia (Phacelia tanacetifolia Benth.). Wirtschaftseigene Futter 32:175-182.

del Baño, M. J., J. Lorente, J. Castillo, O. Benavente-García, J. A. del Río, A. Ortuño, K.-W. Quirin, and D. Gerard. 2003. Phenolic 
diterpenes, flavons, and rosmaric acid distribution during the development of leaves, flowers, stems, and roots of Rosmarinus officinalis. Antioxidant activity. J. Agric. Food Chem. 51:4247-4253.

Dewhurst, R. J., K. J. Shingfield, M. R. F. Lee, and N. D. Scollan. 2006. Increasing the concentrations of beneficial polyunsaturated fatty acids in milk produced by dairy cows in high-forage systems. Anim. Feed Sci. Technol. 131:168-206.

Falchero, L., G. Lombardi, A. Gorlier, M. Lonati, M. Odoardi, and A. Cavallero. 2010. Variation in fatty acid composition of milk and cheese from cows grazed two alpine pastures. Dairy Sci. Technol. 90:657-672.

Ferguson, J. D., D. T. Galligan, and N. Thomsen. 1994. Principal descriptors of body condition score in Holstein cows. J. Dairy Sci. 77:2695-2703.

Ferruzzi, M. G., and R. J. Green. 2006. Analysis of catechins from milk-tea beverages by enzyme assisted extraction followed by high performance liquid chromatography. Food Chem. 112:46-50.

Havemose, M. S., M. R. Weisbjerg, W. L. P. Bredie, H. D. Poulsen, and J. H. Nielsen. 2006. Oxidative stability of milk influenced by fatty acids, antioxidants, and copper derived from feed. J. Dairy Sci. 89:1970-1980.

Hinneburg, I., S. Kempe, H.-H. Rüttinger, and R. H. H. Neubert. 2006. Antioxidant and photoprotective properties of an extract from buckwheat herb (Fagopyrum esculentum Moench). Pharmazie 61:237-240.

Jenkins, T. C., R. J. Wallace, P. J. Moate, and E. E. Mosley. 2008. Recent advances in biohydrogenation of unsaturated fatty acids within the rumen microbial ecosystem. J. Anim. Sci. 86:397-412.

Jensen, S. K., A. K. B. Johannsen, and J. E. Hermansen. 1999 Quantitative secretion and maximal secretion capacity of retinol, $\beta$-carotene and $\alpha$-tocopherol into cows' milk. J. Dairy Res. 66:511-522.

Khiaosa-Ard, R., S. F. Bryner, M. R. L. Scheeder, H.-R. Wettstein, F. Leiber, M. Kreuzer, and C. R. Soliva. 2009. Evidence for the inhibition of the terminal step of ruminal $\alpha$-linolenic acid biohydrogenation by condensed tannins. J. Dairy Sci. 92:177-188.

Khiaosa-Ard, R., F. Klevenhusen, C. R. Soliva, M. Kreuzer, and F. Leiber. 2010. Transfer of linoleic and linolenic acid from feed to milk in cows fed isoenergetic diets differing in proportion and origin of concentrates and roughages. J. Dairy Res. 77:331-336.

Kramer, J. K. G., C. B. Blackadar, and J. Zhou. 2002. Evaluation of two GC columns (60-m SUPELCOWAX 10 and 100-m CP Sil 88) for analysis of milkfat with emphasis on CLA, 18:1, 18:2 and 18:3 isomers, and short- and long-chain FA. Lipids 37:823-835.

Leiber, F., M. Kreuzer, D. Nigg, H.-R. Wettstein, and M. R. L. Scheeder. 2005. A study on the causes for the elevated n-3 fatty acids in cow's milk of alpine origin. Lipids 40:191-202.

Li, S. Q., and Q. H. Zhang. 2001. Advances in the development of functional foods from buckwheat. Crit. Rev. Food Sci. Nutr. 41:451-464.

Li, Y., and Q. Meng. 2006. Effect of different types of fibre supplemented with sunflower oil on ruminal fermentation and production of conjugated linoleic acids in vitro. Arch. Anim. Nutr. 60:402411.

Lourenço, M., P. W. Cardozo, S. Calsamiglia, and V. Fievez. 2008. Effects of saponins, quercetin, eugenol, and cinnamaldehyde on fatty acid biohydrogenation of forage polyunsaturated fatty acids in dual-flow continuous culture fermenters. J. Anim. Sci. 86:30453053.

Makkar, H. P. S. 2003. Quantification of Tannins in Tree and Shrub Foliage: A Laboratory Manual. Kluwer Academic Publishers, Dordrecht, the Netherlands.

Mulholland, J. G., and J. B. Coombe. 1979. A comparison of the forage value for sheep of buckwheat and sorghum stubbles grown on the Southern Tablelands of New South Wales. Aust. J. Exp. Agric. Anim. Husb. 19:297-302.
Nozière, P., P. Grolier, D. Durand, A. Ferlay, P. Pradel, and B. Martin. 2006. Variations in carotenoids, fat-soluble micronutrients, and color in cows' plasma and milk following changes in forage and feeding level. J. Dairy Sci. 89:2634-2648.

Oleszek, W., A. Stochmal, and B. Janda. 2007. Concentration of isoflavones and other phenolics in the aerial parts of Trifolium species. J. Agric. Food Chem. 55:8095-8100.

Oomah, B. D., and G. Mazza. 1996. Flavonoids and antioxidative activities in buckwheat. J. Agric. Food Chem. 44:1746-1750.

Pawlosky, R. J., J. R. Hibbeln, J. A. Novotny, and N. Salem. 2001. Physiological compartment analysis of $\alpha$-linolenic acid metabolism in humans. J. Lipid Res. 42:1257-1265.

Prati, S., V. Baravelli, D. Fabbri, C. Schwarzinger, V. Brandolini, A. Maietti, P. Tedeschi, S. Benvenuti, M. Macchia, I. Marotti, A. Bonetti, P. Catizone, and G. Dinelli. 2007. Composition and content of seed flavonoids in forage and grain legume crops. J. Sep. Sci. 30:491-501.

Rettenmaier, R., and W. Schüep. 1992. Determination of vitamins A and $\mathrm{E}$ in liver tissue. Int. J. Vitam. Nutr. Res. 62:312-317.

Rubach, G. 1957. Fütterungsversuch mit Phacelia (Phacelia tanacetifolia Benth.) an Milchkühe. Tierzucht 11:262-265.

Sanz Sampelayo, M. R., Y. Chilliard, P. Schmidely, and J. Boza. 2007. Influence of type of diet on the fat constituents of goat and sheep milk. Small Rumin. Res. 68:42-63.

Scheller, H. 1981. Die wichtigsten Pflanzen im ZwischenfruchtbauPhazelia. Page 268 in Die Landwirtschaft, Bd. 1, Teil B Pflanzliche Erzeugung. BLV Verlagsgesellschaft, Munich, Germany.

Scollan, N. D., M. R. F. Lee, and M. Enser. 2003. Biohydrogenation and digestion of long chain fatty acids in steers fed on Lolium perenne bred for elevated levels of water-soluble carbohydrate. Anim. Res. 52:501-511.

Sims, J. R., D. J. Solum, M. P. Westcott, G. D. Jackson, G. D. Kushnak, D. M. Wichman, L. E. Welty, R. K. Berg, J. L. Eckhoff, G. F. Stallknecht, and K. M. Gilberthen. 1991. Yield and Bloat Hazard of Berseem Clover and Other Forage Legumes in Montana. Montana State Univ. Agric. Exp. Station, Bozeman.

Sood, S., and P. K. Nagar. 2003. Changes in abscisic acid and phenols during flower development in two diverse species of rose. Acta Physiol. Plant. 25:411-416.

Suter, B., K. Grob, and B. Pacciarelli. 1997. Determination of fat content and fatty acid composition through 1-min transesterification in the food sample: Principles. Z. Lebensm. Unters. Forsch. A. 204:252-258.

Tyagi, A., M. Saluja, C. Kathirvelan, and K. K. Singhal. 2009. Enhancement of the conjugated linoleic acid and vitamin $\mathrm{A}$ and $\mathrm{E}$ contents in goat milk through green fodder feeding. Int. J. Dairy Technol. 62:7-14.

van Dorland, H. A., M. Kreuzer, H. Leuenberger, and H.-R. Wettstein. 2008. Comparative potential of white and red clover to modify the milk fatty acid profile of cows fed ryegrass-based diets from zerograzing and silage systems. J. Sci. Food Agric. 88:77-85.

Van Soest, P. J., J. B. Robertson, and B. A. Lewis. 1991. Methods for dietary fiber, neutral detergent fiber, and nonstarch polysaccharides in relation to animal nutrition. J. Dairy Sci. 74:3583-3597.

Vlaeminck, B., V. Fievez, A. R. J. Cabrita, A. J. M. Fonseca, and R. J. Dewhurst. 2006. Factors affecting odd- and branched-chain fatty acids in milk: A review. Anim. Feed Sci. Technol. 131:389-417.

Watanabe, M. 1998. Catechins as antioxidants from buckwheat (Fagopyrum esculentum Moench) groats. J. Agric. Food Chem. 46:839-845.

Wettstein, H.-R., M. R. L. Scheeder, F. Sutter, and M. Kreuzer. 2001. Effect of lecithins partly replacing rumen-protected fat on fatty acid digestion and composition of cow milk. Eur. J. Lipid Sci. Technol. 103:12-22.

Wijngaard, H. H., and E. K. Arendt. 2006. Buckwheat. Cereal Chem. $83: 391-401$ 